\title{
Effect of the freezing medium on the survival of rabbit eggs after deep freezing
}

\author{
Y. Tsunoda and T. Sugie \\ National Institute of Animal Industry, Chia-shi, 280 Japan
}

The development of frozen-thawed rabbit eggs to near term or term young has been reported by Bank \& Maurer (1974), Whittingham \& Adams (1976) and Tsunoda \& Sugie (1977). The proportions of frozen-thawed eggs surviving in the first two studies were similar (6-7\%) and poor compared with that of unfrozen rabbit eggs. In our study (Tsunoda \& Sugie, 1977) the proportion of frozen-thawed late morulae developing to term did not differ from that of unfrozen rabbit eggs (64 versus $63 \%$ ), but the proportion of eggs frozen at the 8-16-cell (early morula) and 2-cell stages was still poor ( 37 and $13 \%$ ). Since Whittingham (1971) reported that mouse eggs survived after freezing and thawing when the eggs were suspended in modified Dulbecco's buffered medium (PBS), this medium has been used in most studies, irrespective of species, except those of Utsumi \& Yuhara (1975) and Bilton \& Moore (1976) who used Ringer or PBS supplemented with rat or goat serum for freezing rat or goat eggs. The importance of serum in the suspending medium for low-temperature preservation of eggs has been pointed out by Hafez (1971). We therefore examined the effects of different freezing media, especially the presence of serum, on the survival of frozen-thawed rabbit eggs.

Eggs at the 8-16-cell stage (early morula) were recovered in Ringer solution containing $4 \mathrm{mg}$ bovine serum albumin (BSA)/ml or PBS at $45 \mathrm{~h}$ post coitum from 59 mature New Zealand White rabbits which had been induced to superovulate by treatment with FSH (Armour Co.) and HCG (Teikokuzoki, Co., Japan) as described by Kennelly \& Foote (1965). The eggs which appeared morphologically normal after recovery were washed in two changes of medium and then moved to $0.1 \mathrm{ml}$ of each test medium contained in a 1-ml plastic straw. The test media were Ringer's solution containing $4 \mathrm{mg} \mathrm{BSA} / \mathrm{ml}$, PBS (Whittingham, 1971), Brackett \& Williams' medium (B \& W) (Brackett \& Williams, 1968) and these three media supplemented with $50 \%$ rabbit serum. In some experiments, rat, goat, sheep or calf serum was also used. When serum was added to the chemically defined media, BSA was not used. The eggs were equilibrated with $1.5 \mathrm{M}$-dimethylsulphoxide (DMSO) at $37^{\circ} \mathrm{C}$ for $15 \mathrm{~min}$. The samples were cooled to $-76^{\circ} \mathrm{C}$ at $1{ }^{\circ} \mathrm{C} / \mathrm{min}$, then transferred to liquid nitrogen at $-196^{\circ} \mathrm{C}$ and preserved for $1-14$ days. The samples were warmed from $-80^{\circ} \mathrm{C}$ to $0^{\circ} \mathrm{C}$ at approximately $4^{\circ} \mathrm{C} / \mathrm{min}$ as described elsewhere (Tsunoda, Parkening \& Chang, 1976; Tsunoda \& Sugie, 1977). At thawing, the DMSO was diluted out in a step-wise manner with each freezing medium at $37^{\circ} \mathrm{C}$. The eggs were washed with Ringer's solution containing $50 \%$ rabbit serum and cultured for $3-4$ days to determine the number of blastocysts developing in vitro. In two experiments, the frozen-thawed eggs were transferred directly after thawing to the oviducts of 10 synchronous pseudopregnant does (6-12 eggs per recipient) which were allowed to go to term. The transfers were performed on Day 2 of pseudopregnancy. Statistical significance was determined by the $\chi^{2}$ test.

Table 1 shows that the proportion of eggs which appeared morphologically normal after thawing from the various media did not differ significantly. When serum was omitted from the freezing medium, the proportions of eggs developing to blastocysts from 8-16-cell eggs frozen with PBS $(52 \%)$ or B \& W medium ( $68 \%$ ) did not differ but were significantly higher than that of eggs frozen in Ringer's fluid ( $30 \%$ ). The addition of glucose to Ringer's solution had no effect on the proportion of eggs developing into blastocysts.

A significantly higher proportion of eggs frozen and thawed in PBS or Ringer with added rabbit serum developed into blastocysts than in the absence of serum, and rabbit, goat and rat sera, but not calf or sheep sera, had a significant effect on the survival of rabbit eggs.

Addition of rabbit serum to PBS resulted in the birth of 21 live young to 5 does from 43 eggs ( $49 \%$ ) transferred to the 5 does, while only $2 / 5$ females became pregnant and 5 young were born from 35 eggs $(14 \%)$ when PBS was used alone as the freezing medium. 
Table 1. Effect of the freezing medium on the survival of rabbit eggs after freezing and thawing

\begin{tabular}{lcccc}
\hline \multicolumn{1}{c}{ Medium } & $\begin{array}{c}\text { No. of eggs } \\
\text { frozen }\end{array}$ & $\begin{array}{c}\text { No. of normal eggs } \\
\text { after thawing (\%) }\end{array}$ & $\begin{array}{c}\text { No. of eggs } \\
\text { cultured }\end{array}$ & $\begin{array}{c}\text { No. of blastocysts } \\
\text { after culture (\%) }\end{array}$ \\
\hline PBS & 177 & $131(74)$ & 91 & $42(52)$ \\
PBS + rabbit serum & 127 & $112(88)$ & 58 & $46(79)^{* *}$ \\
$\quad$ + calf serum & 37 & $31(84)$ & 28 & $19(68)$ \\
$\quad$ + sheep serum & 58 & $49(84)$ & 36 & $21(58)$ \\
$\quad$ + goat serum & 49 & $45(92)$ & 44 & $36(82)^{* *}$ \\
$\quad$ + rat serum & 51 & $46(90)$ & 46 & $36(78)^{*}$ \\
Ringer & 90 & $79(88)$ & 79 & $24(30)$ \\
Ringer + 1 mg glucose/ml & 51 & $44(86)$ & 44 & $14(32)$ \\
$\quad$ + 5 mg glucose/ml & 34 & $25(74)$ & 25 & $7(28)$ \\
$\quad$ + rabbit serum & 50 & $36(72)$ & 25 & $22(61)^{* *}$ \\
B \& W & 35 & $25(71)$ & 36 & $24(68)$ \\
B \& W + rabbit serum & 45 & $36(80)$ & 25 & 24 \\
\hline
\end{tabular}

Significantly different from the respective values obtained with chemically defined media : ${ }^{*} P<0.01,{ }^{* *} P<0.001$.

In the present study, the eggs were usually stored in Ringer's solution containing $4 \mathrm{mg} \mathrm{BSA} / \mathrm{ml}$ for 1-3 h at $37^{\circ} \mathrm{C}$ before transfer into each freezing medium and it is therefore possible that any eggs which failed to develop into blastocysts after freezing and thawing were damaged during freezing or thawing rather than before freezing.

The present results with PBS alone confirm our earlier transfer report (Tsunoda \& Sugie, 1977). Although Whittingham \& Adams (1976) reported that the viability of frozen-thawed rabbit eggs after transfer was not correlated with the higher rates of development in vitro to morulae and blastocysts, we found a significantly higher pregnancy rate and survival to term after transfer of rabbit eggs frozen in PBS + rabbit serum than that obtained by assessing the survival of frozen-thawed eggs in vitro. The proportion of $49 \%$ with PBS + rabbit serum was clearly higher than the $37 \%$ of our earlier study (Tsunoda \& Sugie, 1977), the $10 \%$ of Bank \& Maurer (1974) or the $15 \%$ of Whittingham \& Adams (1976) and comparable with that of unfrozen 8-16-cell rabbit eggs after transfer (58\%: Bank \& Maurer, 1974; 63\%. Tsunoda \& Sugie, 1977).

The component(s) of serum which are important for the freezing of rabbit eggs should be further investigated.

\section{References}

BANK, H. \& MAURER, R.R. (1974) Survival of frozen rabbit embryos. Expl Cell Res. 89, 188-196.

BILton, R.J. \& MOORE, N.W. (1976) In vitro culture, storage and transfer of goat embryos. Aust. J. biol. Sci. 29, 125-129.

BRACKeTt, B.C. \& Williams, W.L. (1968) In vitro fertilization of rabbit eggs. J. exp. Zool. 160, 271-282.

HAFEZ, E.S.E. (1971) Egg storage. In Methods in Mammalian Embryology, pp. 117-132. Ed. J. C. Daniel, Jr. W. H. Freeman and Company, San Francisco.

KeNNELLY, J.J. \& Foote, R.H. (1965) Superovulatory response of pre- and post-pubertal rabbits to commercially available gonadotrophins. $J$. Reprod. Fert. 9, 177-188.
Tsunoda, Y. \& Sugre, T. (1977) Survival of rabbit eggs preserved in plastic straws in liquid nitrogen. $J$. Reprod. Fert. 49, 173-174.

Tsunoda, Y., Parkening T.A. \& Chang, M.C. (1976) In vitro fertilization of mouse and hamster eggs after freezing and thawing. Experientia 32, 223-224.

UTSUMI, K. \& YUHARA, M. (1975) Survival of rat eggs after freezing and thawing. Jap. J. Fert. Steril. 20, 102, Abstr.

WhitTinghaM, D.G. (1971) Survival of mouse embryos after freezing and thawing. Nature, Lond. 233, 125126.

Whittingham, D.G. \& Adams, C.E. (1976) Low temperature preservation of rabbit embryos. $J$. Reprod. Fert. 47, 269-274. 